\title{
Expression and regulation of oestrogen receptors in the human corpus luteum
}

\author{
Sander van den Driesche, Victoria M Smith, Michelle Myers and W Colin Duncan \\ Obstetrics and Gynaecology, Department of Reproductive and Developmental Sciences, The Queen's Medical \\ Research Institute, Centre for Reproductive Biology, University of Edinburgh, 47 Little France Crescent, Edinburgh \\ EH16 4TJ, Scotland, UK
}

Correspondence should be addressed to $S$ van den Driesche; Email: svddries@staffmail.ed.ac.uk

\begin{abstract}
The molecular mechanisms underlying the control of corpus luteum lifespan in women are not fully understood. Oestradiol has various luteolytic, or luteotrophic, functions in some species, and as it is synthesised within the human corpus luteum, it is an excellent candidate molecule to be a paracrine regulator of luteal function. This study aimed to comprehensively investigate the expression, regulation and effects of oestrogen receptors (ER) in human luteal cells. Genomic oestrogen receptors ER $\alpha$, ER $\beta 1$ and ERß2 were immunolocalised in human corpora lutea from throughout the luteal phase. mRNA expression was investigated throughout the luteal phase and after luteal rescue with exogenous human chorionic gonadotrophin (hCG). The regulation of ER expression and oestradiol action was investigated in cultures of luteinised granulosa cells. ER subtypes ERß1 and ERß2 were localised throughout the luteal phase to steroidogenic cells in the human corpus luteum and cells of the surrounding stroma. Unlike follicular granulosa cells, steroidogenic cells in the corpus luteum showed minimal ER $\alpha$ immunostaining. The presence of endothelial cells in the granulosa cell layer with ER $\beta 1$ and ER 32 positive nuclei was noted. $E R \beta 1$ and $E R \beta 2$ were differentially regulated across the luteal phase with $E R \beta 1$ maximally expressed in the mid-luteal phase, while ERB2 expression was maximal in the early luteal phase. In vivo and in vitro, hCG had no long-term effect on ER expression, although in vitro hCG and oestradiol acutely down-regulated ERs. Treatment with oestradiol in vitro down-regulated 11ß-hydroxysteroid dehydrogenase type 1 and inhibin $\beta$ A subunit confirming a functional oestradiol response. These data highlight functional and differentially regulated oestradiol reception in human luteal cells.

Reproduction (2008) 135 509-517
\end{abstract}

\section{Introduction}

The molecular regulation of luteolysis and maternal recognition of pregnancy in women is still not fully understood (Duncan 2000). In other species the understanding of luteolysis is more advanced. A common pattern is the release of a luteolytic factor from the uterus, prostaglandin $F_{2 \alpha}$, which can be suppressed by the conceptus (McCracken et al. 1970, Hansel et al. 1973). This is not the case in women, as hysterectomy does not prolong the lifespan of the corpus luteum (Niswender et al. 2000). Luteolysis is also not initiated through endocrine changes in pituitary hormones. Maintaining the luteinising hormone (LH) pulse frequency during the luteal phase does not affect luteolysis (Hutchison et al. 1986). These data suggest that factors involved in luteolysis are locally produced and active within the corpus luteum itself.

In simulated early pregnancy, human chorionic gonadotrophin (hCG) has effects on immune cells, endothelial cells and fibroblasts (Duncan et al. 1998a, 1998b, Duncan 2000, Wulff et al. 2001) which do not express LH/hCG receptors (LHCGR). Therefore, if paracrine molecules, which are regulated by hCG, are involved in luteolysis, these molecules should be the products of steroidogenic cells and have receptors on target cells. Indeed, using this approach we have recently identified activin $A$ as a candidate paracrine regulator of tissue remodelling during luteolysis in women (Myers et al. 2007a).

We have also investigated progesterone as a locally produced molecule with receptors on various luteal cell types (Maybin \& Duncan 2004). While progesterone is an attractive paracrine regulatory molecule in the corpus luteum (Vega \& Devoto 1997, Stouffer 2003), characterisation of important and clear luteal effects of progesterone has remained elusive (Devoto et al. 2002a, $2002 b)$. The same cannot be said for oestrogen. Oestrogen has a clear role in the regulation of luteal function in some species (Niswender et al. 2000).

Previously, it was thought that oestradiol did not have effects in the primate corpus luteum based on the lack of expression of oestrogen receptors (ER) in the corpus luteum of rhesus monkeys (Chandrasekher et al. 1994). 
After the discovery of $E R \beta$, this was reinvestigated and $E R \beta$ has been reported in the corpus luteum of marmoset monkeys and women (Saunders et al. 2000). Since then some studies have reported equal levels of $E R \alpha$ (ESR1) and $E R \beta$ (ESR2) mRNA in the human corpus luteum (Misao et al. 1999) and others suggest that $E R \beta$ might be dominantly expressed over $E R \alpha$ (Hosokawa et al. 2001). Although studies of $E R \alpha$ and $E R \beta$ have been reported in the rat (Byers et al. 1997, Telleria et al. 1998, Sar \& Welsch 1999) and rhesus monkey (Duffy et al. 2000) corpus luteum, and in human luteinised granulosa cells (Chiang et al. 2000), the differential regulation, cellular localisation and the role of ERs in human luteal cells remain uncertain.

This study therefore aims to (1) investigate the localisation and expression of $E R \alpha, E R \beta 1$ and ER $\beta 2$ in human corpus luteum across the luteal phase; (2) investigate the cellular localisation of these receptors; (3) determine whether mRNA expression is regulated by hCG in vivo and in vitro; and (4) study whether oestradiol regulates the mRNA expression of key regulators of luteal function in cultures of luteinised granulosa cells in vitro.

\section{Results}

\section{Localisation of ER subtypes in human ovary}

Nuclear staining was observed for ER $\alpha$ (Fig. 1B), ER $\beta 1$ (Fig. 1C) and ERß2 (Fig. 1D) in the human ovary, while no staining could be detected in negative control sections (Fig. $1 \mathrm{~A}$ ). ER $\beta 1$ and ER $\beta 2$ are both expressed in the nuclei of follicular and luteal granulosa cells (Fig. 1C and D

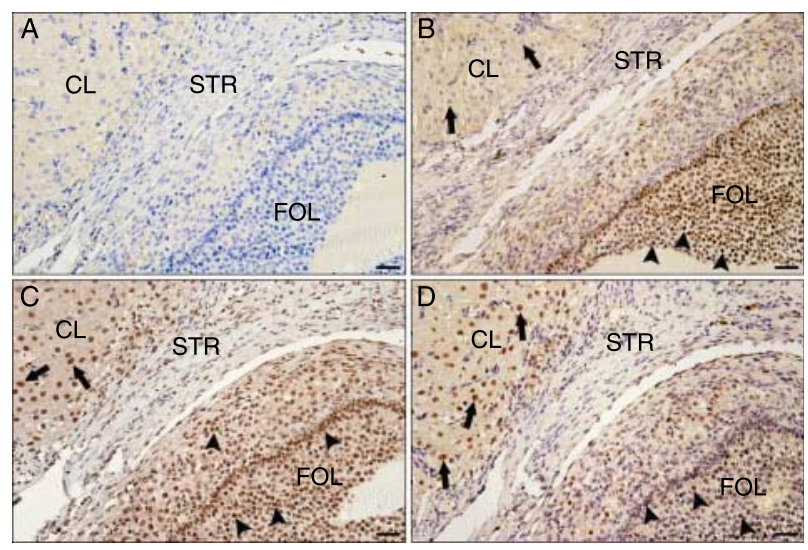

Figure 1 Immunolocalisation of oestrogen receptor subtypes in the human ovary. (A) Negative control section of human ovary showing a corpus luteum (CL), an antral follicle (FOL) and stromal tissue (STR). (B) Immunostaining (brown) for ER $\alpha$ demonstrates its protein localisation in the nuclei of follicular cells (arrowheads), while staining in the cells of the corpus luteum is negligible (arrows). (C) ER $\beta 1$ protein is expressed in the nuclei of cells of the corpus luteum (arrows) and in cells of the antral follicle (arrowheads). (D) Immunolocalisation for ER $\beta 2$ shows a stronger expression in the nuclei of follicular cells (arrowheads) when compared with the cells of the corpus luteum (arrows). Scale bar $=30 \mu \mathrm{m}$. respectively), although $E R \beta 2$ is more strongly expressed in the cells of the corpus luteum than in follicular cells (Fig. 1D). Both ER $\beta 1$ and ER $\beta 2$ show a strong expression in the nuclei of surrounding stromal cells and theca-lutein cells. Immunolocalisation of $E R \alpha$ showed that this receptor is expressed in the nuclei of granulosa cells of antral follicles, while ER $\alpha$ staining in the corpus luteum appeared negative or very weak (Fig. 1B). This suggests that the main receptor in the human corpus luteum is $E R \beta$ and that $E R \alpha$ may be down-regulated in the corpus luteum when compared with the follicle.

\section{Granulosa-lutein cells co-express ER $\beta 1$ and ER $\beta 2$}

Using double immunofluorescence, we then investigated whether luteal steroidogenic cells had both ER $\beta 1$ and ER 32 receptors. As shown in Fig. $2 A$ and $B, E R \beta 1$ (green signal) seems to be the more predominant isoform localised to the nuclei of granulosa-lutein cells when compared with ER $\beta 2$ (red signal). Some cells show a co-localisation of ER $\beta 1$ and ER $\beta 2$ (orange signal), while some cells show only ER $\beta 1$ localisation (arrows) and others show a very weak co-localisation (arrowheads). These data suggest that these receptors co-exist in granulosa-lutein cells. While it is possible that some cells have mainly ER $\beta 1$, no cells with mainly ER $\beta 2$ were detected in any of the sections analysed across the luteal phase.
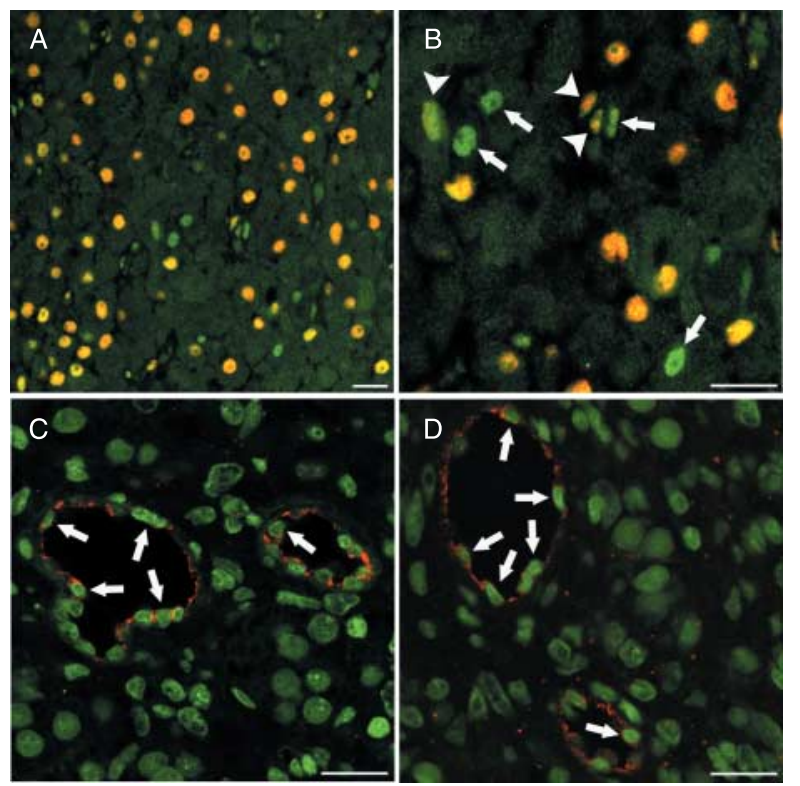

Figure 2 ( $A$ and B) Double immunofluorescence for ER $\beta 1$ (green) and ER $\beta 2$ (red) in a mid-luteal human corpus luteum. Co-localisation of ER $\beta 1$ and ER $\beta 2$ is shown as orange nuclei. Arrows demonstrate cells that only express ER $\beta 1$, while arrowheads demonstrate a very weak co-localisation of ER $\beta 1$ and ER $\beta 2$. (C) Co-localisation (arrows) in another mid-luteal human corpus luteum of ER $\beta 1$ (green) with CD31/PECAM-1 (red), a marker for endothelial cells. (D) Co-localisation (arrows) in the human corpus luteum of ER $\beta 1$ (green) with CD31/PECAM-1 (red). In all cases the scale bars represent $20 \mu \mathrm{m}$. 


\section{$E R \beta 1$ and ERB2 are localised to the nuclei of endothelial cells}

It is clear that ERß1 and ER $\beta 2$ can be localised to different cell types in the human corpus luteum. As the progesterone receptor in the corpus luteum is absent from endothelial cells (Maybin \& Duncan 2004), we investigated whether these cells express ER $\beta$ receptors. Dual immunofluorescence on the slides of the corpus luteum for ER $\beta 1$ or ER $\beta 2$ with CD31/PECAM-1, a welldescribed marker for endothelial cells (Cao et al. 2002) revealed that both ER $\beta 1$ and ER $\beta 2$ are expressed in the nuclei of endothelial cells (see arrows in Fig. 2C and D respectively) at all stages of the luteal phase. Thus, luteal microvascular endothelial cells have the capacity to directly respond to oestradiol.

\section{Immunolocalisation of ER $\beta 1$ and $E R \beta 2$ across the luteal phase}

Next, we analysed the possibility that expression of ER may vary throughout the luteal phase. Immunohistochemistry for ER $\beta 1$ and ER $\beta 2$ was analysed in early, midand late luteal phase corpora lutea (Fig. 3). Positive immunostaining for ER $\beta 1$ and $E R \beta 2$ was observed in the nuclei of both granulosa-lutein cells and theca-lutein cells, for all sections classified as either early, mid- or late luteal phase, based on cell morphology (Maybin \& Duncan 2004). Positive immunostaining could also be seen throughout the luteal phase in some of the cells in
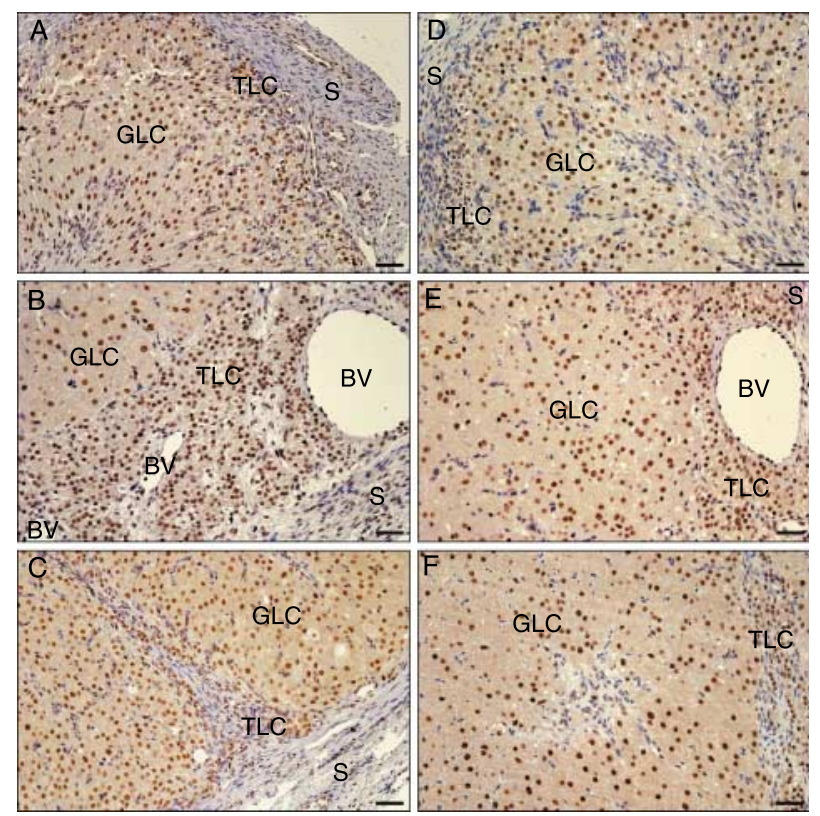

Figure $3 E R \beta 1$ expression in human corpus luteum during $(A)$ the early luteal, (B) mid-luteal and (C) late luteal stages of the luteal phase, and (D) ER $\beta 2$ expression in human corpus luteum during the early luteal, (E) mid-luteal and (F) late luteal phase. BV, blood vessel; GLC, granulosa-lutein cell; S, stroma and TLC, theca-lutein cell. Scale bars $=30 \mu \mathrm{m}$. the stromal areas (Fig. 3). Using the same immunostaining intensity scoring system that revealed a downregulation of progesterone receptor in the late luteal phase (Duncan et al. 2005a), no differences were observed in ER $\beta 1$ or ERß2 immunostaining during different stages of the luteal cycle in any cell compartment $(P<0.05$, Kruskal-Wallis test; data not shown).

\section{The effect of hCG on the expression of ER in human corpora lutea in vivo}

In order to determine the effect of hCG on the luteal expression of ER in women, mRNA expression for ERs was examined in archival corpora lutea tissues collected from early, mid, late and rescue stages of the luteal phase. Although we could not immunolocalise $E R \alpha$ in the human corpus luteum (Fig. 1B), its mRNA is expressed at a low level. There were no changes across the luteal phase or after hCG exposure to mimic maternal recognition of pregnancy (Fig. 4A). There was, however, evidence of changing expression of the $E R \beta$ receptors. $E R \beta 1 \mathrm{mRNA}$ expression was maximal in
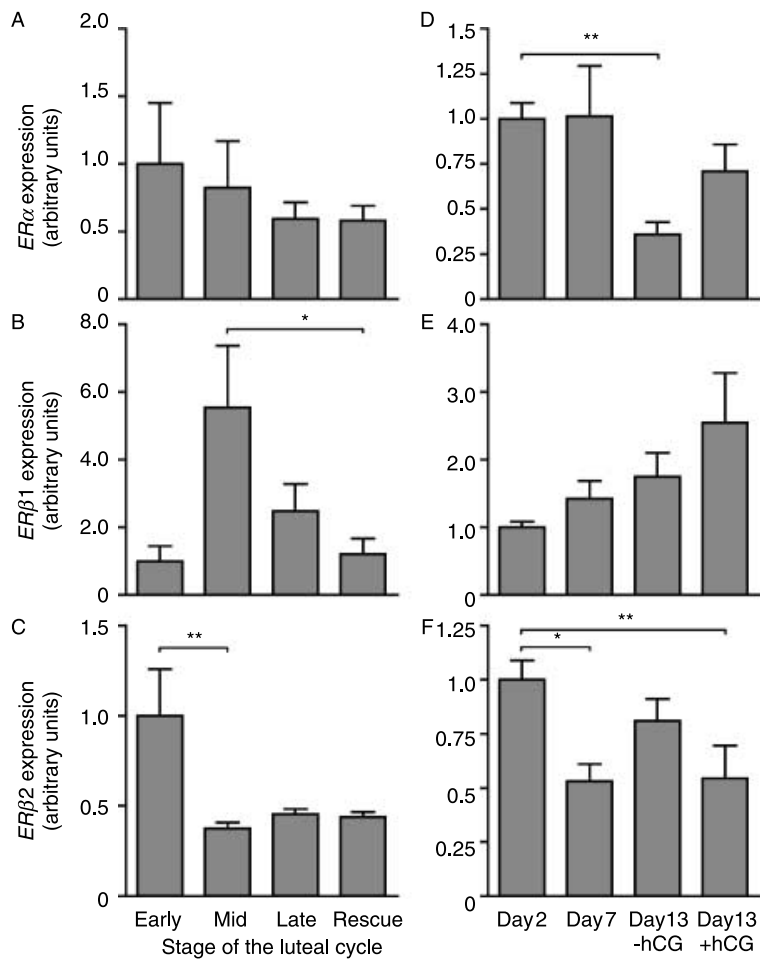

Figure $4(\mathrm{~A}-\mathrm{C})$ In vivo mRNA expression of oestrogen receptors in human corpora lutea during the luteal phase. (A) $E R \alpha$, (B) $E R \beta 1$ and (C) $E R \beta 2$ expressions are shown in the early $(\mathrm{LH}+1$ to $\mathrm{LH}+5)$, mid$(\mathrm{LH}+6$ to $\mathrm{LH}+10)$ and late $(\mathrm{LH}+11$ to $\mathrm{LH}+14)$ luteal phases and after treatment with hCG from $\mathrm{LH}+7$ for 5-8 days (rescue). (D-F) In vitro chronic manipulation with hCG in luteinised granulosa cell cultures designed to mimic the luteal phase. Fresh cultures (day 2) were treated with low dose hCG until day 7 , and then hCG was increased (day $13+\mathrm{hCG}$ ) or removed (day $13-\mathrm{hCG}$ ). (D) $E R \alpha$, (E) $E R \beta 1$ and (F) $E R \beta 2$ expressions. ( ${ }^{*} P<0.05$; ${ }^{* *} P<0.01$, Kruskal-Wallis test). 
the mid-luteal phase (Fig. 4B) and luteal rescue reduced mRNA expression $(P<0.05$, Kruskal-Wallis test) when compared with the mid-luteal phase. The pattern was different when $E R \beta 2 \mathrm{mRNA}$ expression was investigated. It was maximal in the early luteal phase (Fig. 4C) and expression was significantly lower in the mid-luteal phase compared with the early luteal phase $(P<0.01$, Kruskal-Wallis test). There were no differences after exposure to hCG in vivo to rescue the corpus luteum (Fig. 4C). These data suggest that $E R \beta 1$ and $E R \beta 2$ may be differentially regulated across the luteal phase.

\section{Differential expression of ERs in the prolonged cultures of luteinised granulosa cells}

As different cells express ERßs in the human corpus luteum (Figs 1 and 3), we investigated granulosa-lutein cell expression separately using a novel model system of prolonged cultures of luteinised granulosa cells to mimic the human luteal phase and luteal rescue in the absence of other cell types (Duncan et al. 2005a). In vitro, ER $\alpha$ mRNA expression was decreased in prolonged cultures when hCG had been removed (Fig. 4D). The mRNA expression of $E R \beta 1$ (Fig. 4E) was not significantly different in these in vitro cultures of luteinised granulosa cells mimicking the luteal phase $(P>0.05$, KruskalWallis test). In contrast, $E R \beta 2 \mathrm{mRNA}$ expression (Fig. 4F) was reduced in 7-day cultures $(P<0.05$, Kruskal-Wallis test) and 13-day cultures with hCG $(P<0.01$, KruskalWallis test) when compared with 2-day cultures.

\section{HCG actively regulates ER expression in vitro}

As it seems that ERs may be differentially regulated, we investigated whether hCG had differential effects on the mRNA expression of the different ER isoforms in the short term. The treatment of cultured human luteinised granulosa cells with $100 \mathrm{ng} / \mathrm{ml}$ hCG for $24 \mathrm{~h}$ resulted in a significant down-regulation of $E R \alpha(P<0.05, t$-test; Fig. 5A), $E R \beta 1(P<0.05$, t-test; Fig. 5B) and $E R \beta 2$ $(P<0.05$, t-test; Fig. 5C) mRNA expression. This confirms that ERs can be regulated in luteal steroidogenic cells acutely, but suggests that the differential effects seen in $E R \beta 1$ and $E R \beta 2$ mRNA expression are not a result of acute $\mathrm{LH} / \mathrm{hCG}$ signalling per se.

\section{Luteinised granulosa cells have a functional oestrogen signalling pathway}

Finally, we determined the functional effects of oestradiol on the cultures of luteinised granulosa cells in vitro. Using physiological concentrations (Andersen \& Hornnes 1994), treatment with oestradiol $\left(10^{-6} \mathrm{~mol} / \mathrm{l}\right.$ for $24 \mathrm{~h}$ ) could down-regulate the mRNA expression of both $E R \alpha(P<0.01, t$-test; Fig. 5D) and $E R \beta 1(P<0.05$,
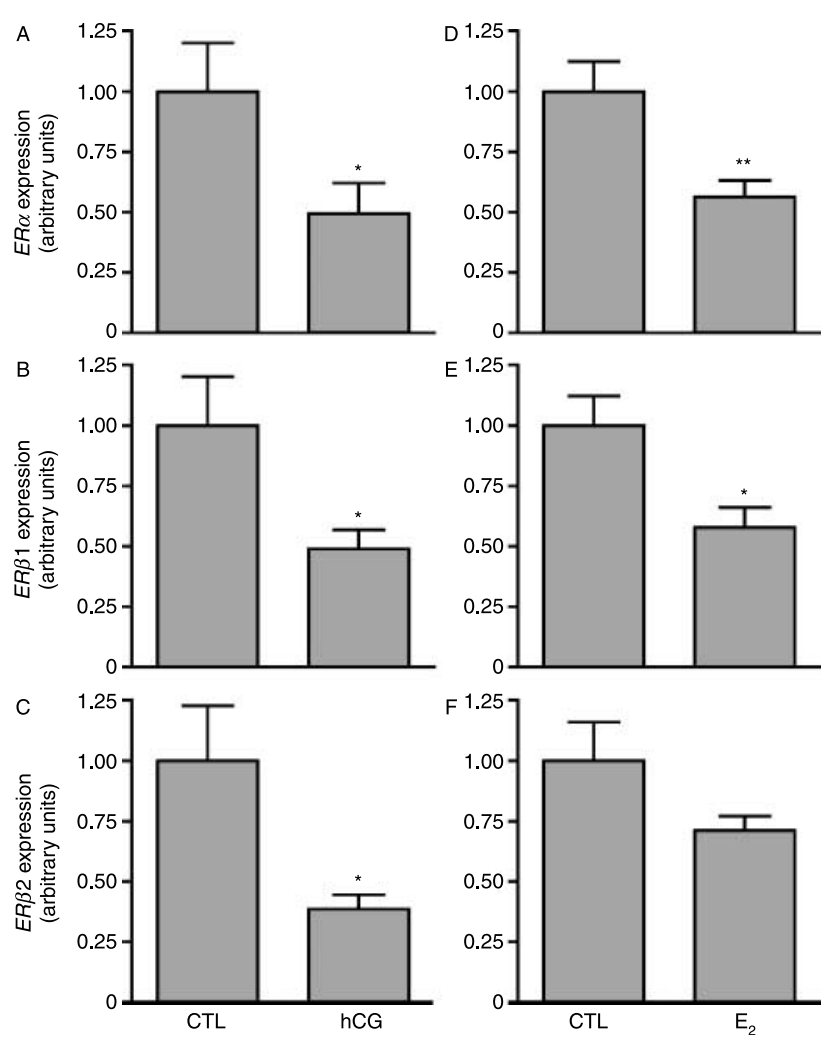

Figure 5 (A-C) Short-term stimulation of luteinised granulosa cells with $100 \mathrm{ng} / \mathrm{ml}$ hCG for $24 \mathrm{~h}$ significantly down-regulated the mRNA expression of (A) $E R \alpha$, (B) $E R \beta 1$ and (C) $E R \beta 2$. (D-F) Short-term stimulation of luteinised granulosa cells with $10^{-6} \mathrm{~mol} / \mathrm{l}$ oestradiol $\left(E_{2}\right)$ for $24 \mathrm{~h}$ significantly down-regulated the mRNA expression of (D) $E R \alpha$ and $(\mathrm{E}) E R \beta 1$ although $(\mathrm{F})$ the tendency for reduction in $E R \beta 2 \mathrm{mRNA}$ expression was not significant $\left({ }^{*} P<0.05 ;{ }^{*} P<0.01\right.$, $t$-test).

$t$-test; Fig. 5E). There appeared to be no effect on $E R \beta 2$ $(P=0.1090, t$-test; Fig. 5F).

Investigation of other important factors in the corpus luteum showed that oestradiol has no effect on the mRNA expression of LHCGR (Fig. 6A), StAR protein (STAR; Fig. 6B), vascular endothelial growth factor (VEGF; Fig. 6C) and connective tissue growth factor (CTGF; $P=0.0976$, $t$-test; Fig. 6D) in luteinised granulosa cell cultures. However, oestradiol significantly down-regulates the mRNA expression of inhibin $\beta A$ subunit (INHBA; $P<0.05$, t-test; Fig. 6E) and $11 \beta$-hydroxysteroid dehydrogenase type 1 (HSD11B1; $P<0.05, t$-test; Fig. $6 F)$ in these cultures.

\section{Discussion}

This study has investigated genomic ERs in the human corpus luteum across the luteal phase. The regulation and effects of these receptors have been further analysed using an established model of luteinised granulosa cell cultures in vitro. We have shown that, in contrast to follicular granulosa cells, granulosa-lutein cells tend to immunolocalise $E R \beta$ rather than $E R \alpha$. Both $E R \beta 1$ and 

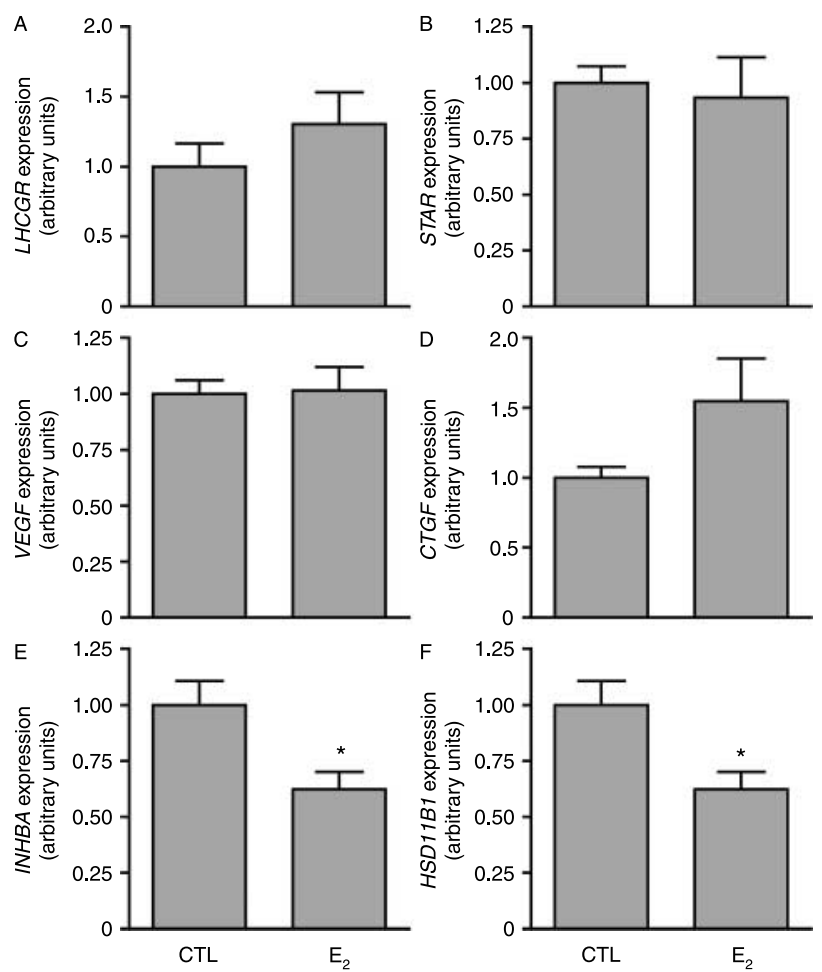

Figure 6 Short-term stimulation of luteinised granulosa cells with $10^{-6} \mathrm{~mol} / \mathrm{l}$ oestradiol $\left(\mathrm{E}_{2}\right)$ for $24 \mathrm{~h}$ has no statistically significant effects on the mRNA expression of (A) LH/hCG-R (LHCGR), (B) STAR, (C) VEGF and (D) CTGF. (E) Inhibin $\beta A$ subunit (INHBA) and (F) $11 \beta \mathrm{HSD}$ type 1 (HSD11B1) were significantly down-regulated after stimulating luteinised granulosa cells with $10^{-6} \mathrm{~mol} / / \mathrm{l}$ oestradiol for $24 \mathrm{~h}\left({ }^{*} P<0.05, t\right.$-test $)$.

ER $\beta 2$ are expressed in various luteal cell types across the luteal phase, including endothelial cells. The role of these receptors is not clear, but we provide evidence for a functional ER pathway in luteinised granulosa cells and evidence that $E R \beta 1$ and $E R \beta 2$ mRNA expression is regulated and that this regulation may be differential for each receptor type.

Previous investigation into ER expression in the corpora lutea of women produced some contradictory results. One study showed $E R \alpha$ and $E R \beta$ transcripts to be co-expressed at similar levels (Misao et al. 1999), while another showed ER $\alpha$ protein in the follicles but not in the corpus luteum (Taylor \& Al-Azzawi 2000). Further studies reported $E R \beta$ protein in human luteal tissue (Saunders et al. 2000, Taylor \& Al-Azzawi 2000). We have confirmed that human corpora lutea express mRNA for $E R \alpha$ and $E R \beta 1$ and shown $E R \beta 2$ expression. In addition, we have been able to immunolocalise $\mathrm{ER} \alpha$ to the follicle but not the corpus luteum, whereas ER $\beta 1$ and ER $\beta 2$ could be immunolocalised to the corpus luteum. The human corpus luteum expresses both ER $\beta 1$ and ER $\beta 2$ message and protein.

There seems to be regulation across the normal luteal phase in the expression of these receptors. ER $\beta 1 \mathrm{mRNA}$ is maximally expressed in the mid-luteal phase, while
$E R \beta 2 \mathrm{mRNA}$ expression is maximal as the corpus luteum is forming. There is evidence for the regulation of $E R \beta$ in the ovary. Byers et al. (1997) showed that $E R \beta$ mRNA was down-regulated after hCG injection in the rat. What was clear with the pattern of regulation in vivo and in vitro was that $E R \beta 1$ and $E R \beta 2$ appeared to be differentially regulated. What appeared consistent is the tendency for $E R \beta 1$ to rise as the corpus luteum is fully formed or luteinised granulosa cells are cultured, whereas $E R \beta 2$ tends to do the opposite. The reason for such apparent differential regulation is not clear.

It is obvious that granulosa-lutein cells of the corpus luteum express both ER $\beta 1$ and $E R \beta 2$. It is not clear whether some cells have more ER $\beta 1$ or whether this is a function of the detection system, but it seems that if a cell has ER $\beta 2$ it also expresses ER $\beta 1$. It is also clear that any regulation of mRNA cannot be detected clearly at a protein level. This is in contrast to progesterone receptor, where down-regulation is evident in the late luteal phase in vivo and in vitro (Duncan et al. 2005a). It seems that $\mathrm{ER} \beta \mathrm{s}$ are maintained and thus possibly active in the late luteal phase.

The reason for the apparent differential regulation for $E R \beta 1$ and $E R \beta 2$ is not clear. It should be noted that these findings represent $\mathrm{mRNA}$ rather than protein. However, in vitro both the acute hCG and oestradiol treatments tend to have the same effect on the mRNA expression of ERs. This is similar to the down-regulation of $E R \beta \mathrm{mRNA}$ by hCG in rat granulosa cells in vitro (Byers et al. 1997). The effect of chronic exposure to hCG is less marked, however, as there were no differences between late and rescued corpora lutea in vivo and in the corresponding treatments in vitro. The molecules involved in potential differential regulation remain to be determined.

We did not see any differential changes in the immunostaining of various cell types across the luteal phase. However, we did detect both ER $\beta 1$ and ER $\beta 2$ in endothelial cells. This is similar to what is seen in the human endometrium (Critchley et al. 2001) and in contrast to the localisation of progesterone receptors (Maybin \& Duncan 2004). The corpus luteum is associated with intense angiogenesis (Reynolds et al. 2000, Wulff et al. 2001) followed by vascular regression. As oestradiol is produced by the granulosa-lutein cells (Devoto et al. 2002b) of the corpus luteum, with receptors on endothelial cells, it may have potential effects on endothelial cell function. It is not known whether oestradiol has any direct effects, but it is notable that molecules based on oestrogen have been shown to have anti-angiogenic properties (Klauber et al. 1997, Mooberry 2003, Tinley et al. 2003). Oestradiol may therefore have effects on the luteal vasculature.

The effects on granulosa-lutein cells are also not certain. In pilot experiments, we were able to see several effects of the pharmacological concentrations of oestradiol in the cultures of luteinised granulosa cells, but here we investigated the effects of physiological 
concentrations (Andersen \& Hornnes 1994). One major role of these cells is steroidogenesis, but we could not detect acute effects of oestradiol on the major regulators of luteal steroidogenesis $L H C G R$ or STAR.

Both VEGF and CTGF are major regulators of tissue and vascular remodelling in the corpus luteum (Duncan et al. 2005b, Fraser \& Duncan 2005), but oestradiol had no effect on their mRNA expression over $24 \mathrm{~h}$. This was surprising as it has been demonstrated that VEGF has a functional oestrogen response element in its promoter (Hyder et al. 2000) and oestradiol has been shown to up-regulate Ctgf mRNA in rat granulosa cells (Harlow et al. 2007). Others have demonstrated a very rapid increase in VEGF expression after stimulating isolated human endometrial cells (Shifren et al. 1996) or human MCF-7 breast carcinoma cells (Ruohola et al. 1999) as rapidly as $1 \mathrm{~h}$. It may be that such rapid effects do occur or that in these cells the major hormonal regulator is $\mathrm{LH}$. The interaction of oestradiol and $\mathrm{LH}$ on VEGF expression in human luteinised granulosa cells remains to be fully investigated.

We also investigated the effect of oestradiol on two other molecules that seem to be important in human luteal function, namely activin (Myers et al. 2007a) and locally produced glucocorticoids (Myers et al. 2007b). Oestradiol regulated mRNA expression of INHBA and HSD11B1. The importance of this change is not clear, but it suggests the presence of functional ER signalling pathway in these cells.

How much of this is $E R \beta 1$ and how much involves low levels of $E R \alpha$ expression is not clear. ER $\beta 2$ is reported not to bind ligand (Matthews \& Gustafsson 2003) and therefore does not activate the transcription of an oestrogen-sensitive reporter gene. It has a role in heterodimerisation, although with $\mathrm{ER} \alpha$ more so than ERß1 (Ogawa et al. 1998). Whether the role for ERßs in the corpus luteum is to act directly or to function to remove potential classical oestrogen action by a dominant negative route remains unclear. Indeed, there is increasing evidence for the existence of membranebound ERs (Matthews \& Gustafsson 2003) and effects of such molecules have not been considered here, but they may be important.

We have, however, shown the expression of ER $\beta 1$ and $E R \beta 2$ in the corpus luteum, suggested differential regulation and confirmed that luteinised granulosa cells are an additional tool to study ER signalling and differential regulation in vitro.

\section{Materials and Methods}

\section{Collection of human ovarian tissue and human corpora lutea}

Tissue collection was approved by the medical research ethics committee and all women gave informed consent. Normal ovarian tissue was collected from women with regular cycles undergoing hysterectomy for benign conditions. Human corpora lutea $(n=18)$ were enucleated at the time of surgery from women with regular menstrual cycles undergoing hysterectomy for benign conditions and dated on the basis of the urinary LH surge as described previously (Duncan et al. 1996, Duncan 2000). In this study, six corpora lutea were classified as early luteal $(\mathrm{LH}+1$ to $\mathrm{LH}+5)$, six as mid-luteal $(\mathrm{LH}+6$ to $\mathrm{LH}+10)$ and six as late luteal $(\mathrm{LH}+11$ to $\mathrm{LH}+14)$. At operation, the corpus luteum was quartered to ensure that each quarter contained all cellular elements and was fixed in $10 \%(\mathrm{v} / \mathrm{v})$ neutral buffered formalin for subsequent immunohistochemistry. In addition, archival corpora lutea that had been immediately frozen and stored at $-70{ }^{\circ} \mathrm{C}$ from previous studies (Duncan et al. 2005b, Fraser et al. 2005) were also available. Frozen tissue quarters for mRNA extraction were available from three early luteal, seven mid-luteal, six late luteal and five corpora lutea that had been 'rescued' (women were given daily doubling doses of exogenous hCG (Serono Laboratories, Welwyn Garden City, UK), starting at $125 \mathrm{IU}$, from $\mathrm{LH}+7$ for $5-8$ days until surgery) as described previously (Duncan et al. 1996, 1998b).

\section{Isolation of human luteinised granulosa cells}

The medical ethics committee separately approved the collection of cells from patients undergoing assisted conception. With patient consent, follicular fluid was collected from women undergoing transvaginal oocyte retrieval for in vitro fertilisation after ovarian stimulation using a standard procedure (Duncan et al. 2005a). Isolation of luteinised granulosa cells using Percoll density gradient centrifugation was carried out as described previously (Duncan et al. 2005b, Myers et al. 2007a).

\section{HCG treatments in the primary cultures of luteinised granulosa cells}

To investigate the acute effects of hCG and oestradiol, pooled luteinised granulosa cells (100 000 per well of 3-5 patients) were cultured in 24-well plates precoated with Matrigel (BD Biosciences, Bedford, MA, USA) in serum-free medium (supplemented DMEM/F12 Ham mixture), as described previously (Duncan et al. 2005b). Briefly, cells were refreshed with serum-free culture medium every 2 days after until day 6 when they were treated with either $100 \mathrm{ng} / \mathrm{ml}$ hCG (Serono Laboratories), or with $10^{-6} \mathrm{~mol} / \mathrm{l}$ oestradiol in $0.1 \%(\mathrm{v} / \mathrm{v})$ dimethyl sulphoxide (Sigma-Aldrich). Controls contained appropriate concentrations of the carrier solution.

To study the chronic effects of hCG, luteinised granulosa cells were cultured for 13 days as described previously (Duncan et al. 2005a). Briefly, cells were grown in $1 \mathrm{ng} / \mathrm{ml}$ hCG until day 7 when hCG was removed or increased to $100 \mathrm{ng} / \mathrm{ml}$ until day 13 of culture. Cells were analysed on day 2, 7 and 13 in the absence of hCG, and on day 13 with hCG. This regimen mimics the luteal phase and rescue (Duncan et al. 2005a).

In each experiment, three wells were pooled, in triplicate for each treatment for subsequent quantitative real-time PCR analysis. Each experiment was carried out at least three times to avoid biological bias. 


\section{Preparation of cDNA from luteinised granulosa cells cultures}

Luteinised granulosa cell mRNA was extracted using RNeasy mini-spin columns after lysis by the addition of RNeasy lysis buffer (Qiagen). Lysates were frozen until processed as per manufacturers' protocols, then DNase treated with on-column DNasel (Qiagen) and quantified using the NanoDrop ND-1000 Spectrophotometer (NanoDrop Technologies, Wilmington, DE, USA). mRNA was then reverse transcribed into cDNA using random hexamers (Applied Biosystems, Foster City, CA, USA).

\section{Quantitative analysis of gene expression by RT-PCR}

Quantitative real-time PCR (QRT-PCR) was carried out on the ABI PRISM 7900 heat-cycler sequence detection system (Applied Biosystems) using specific primers and probes (Eurogentec, Southampton, UK) for each gene of interest (Table 1) and levels were related to a ribosomal 18s internal control (Applied Biosystems). All samples were performed in duplicate and a relative comparison was made to an appropriate control tissue cDNA.

\section{Immunohistochemistry}

Specific mouse monoclonal antibodies were used for the immunolocalisation of ER $\alpha$ (Clone 6F11, Vector Laboratories, Peterborough, UK), ER $\beta 1$ and ER $\beta 2$ (Clone PPG5/10 and PPG57/3 respectively; Serotec, Oxford, UK) using $5 \mu \mathrm{m}$ paraffin tissue sections of human ovary or human corpora lutea prepared on poly-L-lysine-coated microscopic slides. These sections were dewaxed, rehydrated, washed in PBS, subjected to antigen retrieval by boiling in a pressure cooker in $0.01 \mathrm{~mol} / \mathrm{l}$ citric acid ( $\mathrm{pH} \mathrm{6.0)}$ ) for $5 \mathrm{~min}$ and left to cool to room temperature. All sections were washed and placed in $3 \%(\mathrm{v} / \mathrm{v})$ $\mathrm{H}_{2} \mathrm{O}_{2} /$ methanol for $30 \mathrm{~min}$, followed by an avidin and biotin block (Vector Laboratories) and a further block using normal goat serum (NGS, Diagnostics Scotland, Edinburgh, UK) diluted 1:5 in PBS containing 5\% (w/v) BSA (NGS/PBS/BSA) for $1 \mathrm{~h}$ at room temperature. The sections were incubated overnight in primary antibody diluted 1:20 (ER $\alpha), 1: 50$ (ERß2) or 1:100 (ERß1) in NGS blocking solution at $4{ }^{\circ} \mathrm{C}$.

All sections were then washed twice for $5 \mathrm{~min}$ in PBS plus $0.01 \%(\mathrm{v} / \mathrm{v})$ Tween-20 (PBS-T; Sigma-Aldrich) before incubation with biotinylated goat anti-mouse secondary antibody (DAKO Corp., Cambridge, UK), diluted 1:500 in NGS blocking solution. Incubations lasted for $1 \mathrm{~h}$ and were followed by two washes in PBS-T for $5 \mathrm{~min}$. Thereafter, the sections were incubated in avidin-biotin complex HRP (Vector Laboratories) for $1 \mathrm{~h}$ according to the manufacturer's instructions. All sections were washed in PBS-T $(2 \times 5 \mathrm{~min})$ and bound antibodies visualised by incubation with liquid 3,3'-diaminobenzidine tetra-hydrochloride (DAKO). The sections were counterstained lightly with haematoxylin to enable cell identification. Negative controls for each antibody examined were performed identically to the above protocol with the primary antibody omitted or replaced with non-specific immunoglobulins. Images were captured using an Olympus Corp.

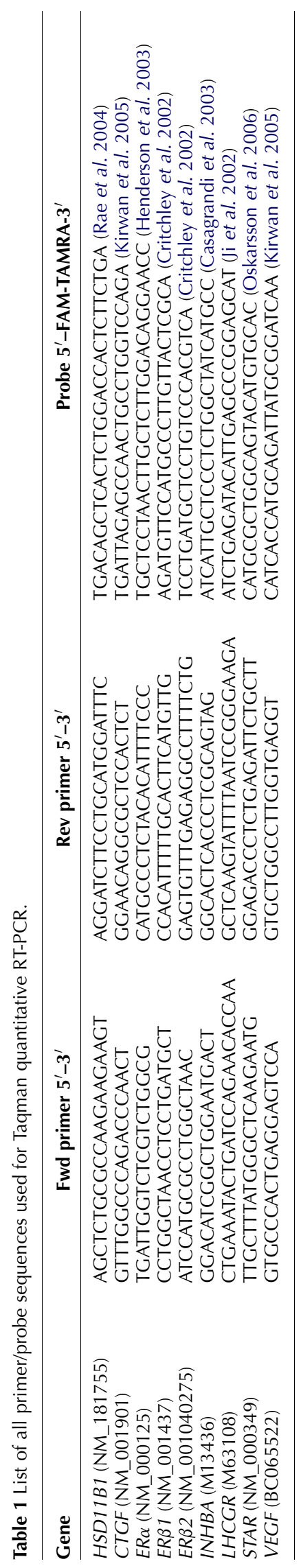

Reproduction (2008) 135 509-517 
Provis microscope (Olympus Corp. Optical Co., London, UK) equipped with a Kodak DCS330 camera (Eastman Kodak Co.), stored on a HP computer and assembled using Photoshop 7.0.1 (Adobe Systems Inc).

\section{Fluorescent immunohistochemistry}

Slides for the co-localisation experiments of ER $\beta 1$ with ER $\beta 2$ were washed, subjected to antigen retrieval and blocked as described above. Mouse anti-ERß1, diluted 1:20 in NGS blocking solution, was incubated on the sections overnight at $4{ }^{\circ} \mathrm{C}$. The sections were then washed in PBS $(2 \times 5 \mathrm{~min})$ and the slides were incubated for 30 min with biotinylated goat antimouse Fab secondary antibody (Abcam, Cambridge, UK), diluted 1:500 in NGS blocking solution. After three washes in PBS, the sections were incubated for $1 \mathrm{~h}$ with avidin Alexa Fluor 488 (Molecular Probes, Paisley, UK) diluted 1:200 in PBS to amplify the ER $\beta 1$ immunostaining with green fluorescence.

For co-localisation with ER $\beta 2$, the sections were washed twice in PBS and then re-blocked with NGS/PBS/BSA containing non-conjugated goat anti-mouse Fab secondary antibody (Abcam) diluted 1:200 for $1 \mathrm{~h}$ and then incubated overnight at $4{ }^{\circ} \mathrm{C}$ with mouse anti-ER $\beta 2$ diluted 1:200 in NGS blocking solution. The sections were washed twice in PBS and incubated for 30 min with goat anti-mouse Fab HRP conjugated secondary antibody (Abcam) diluted 1:500 in NGS blocking solution before being washed twice in PBS and incubated for $10 \mathrm{~min}$ with tyramide Cy3 (TSA plus cyanine 3 system; Perkin-Elmer Life Sciences, Boston, MA, USA) diluted 1:50 in the supplied buffer to amplify the ERß2 immunostaining with red fluorescence.

Slides for the Co-localisation of ER $\beta 1 / E R \beta 2$ with CD31/PECAM-1 were washed, subjected to antigen retrieval and blocked as described above. Mouse anti-CD31/PECAM-1 (Clone JC70A, DAKO), diluted 1:100 in NGS blocking solution, was incubated on the sections overnight at $4{ }^{\circ} \mathrm{C}$. The sections were then washed twice in PBS and the slides were incubated for 30 min with goat anti-mouse Fab HRP conjugated secondary antibody (Abcam), diluted 1:500 in NGS blocking solution. After two washes in PBS, the sections were incubated for $10 \mathrm{~min}$ with tyramide Cy3 (TSA Plus Cyanine 3 System; Perkin-Elmer Life Sciences) diluted $1: 50$ in the supplied buffer to amplify the CD31/PECAM-1 immunostaining with red fluorescence.

For co-localisation with ERß1 or ERß2, the sections were washed twice in PBS and then re-blocked for $1 \mathrm{~h}$ with NGS/PBS/BSA containing non-conjugated goat anti-mouse Fab secondary antibody (Abcam) diluted 1:200 and then incubated overnight at $4{ }^{\circ} \mathrm{C}$ with mouse anti-ER $\beta 1$ or antiER $\beta 2$, both diluted 1:20 in NGS blocking solution. Sections were washed twice in PBS and incubated with biotinylated goat anti-mouse Fab secondary antibody (Abcam) diluted 1:500 in NGS blocking solution for 30 min. After two washes in PBS, sections were incubated for $1 \mathrm{~h}$ with avidin Alexa Fluor 488 (Molecular Probes) diluted 1:200 in PBS to amplify the $E R \beta 1$ or ER $\beta 2$ immunostaining with green fluorescence.

Slides were washed twice in PBS and mounted in Permafluor (Beckman Coulter, High Wycombe, UK). Fluorescent images were captured using an LSM 510 Axiovert 100 M confocal laser microscope (Carl Zeiss Ltd, Welwyn Garden City, UK). All images were compiled using Photoshop 7.0.1 (Adobe Systems Inc).

\section{Statistical analysis}

Statistical analyses used are highlighted in the figure legends. Parametric statistics were used if the data were normally distributed with appropriate s.D.s (GraphPad Prism version 4.0c for Macintosh; GraphPad Software, San Diego, CA, USA). If the data were not normally distributed non-parametric statistics were used. Groups were analysed by Kruskal-Wallis nonparametric test and Dunn's multiple comparison test. Differences were considered significant at $P<0.05$ level. The intensity of immunostaining for ER in granulosa-lutein cells, theca-lutein cells and stroma cells was carried out by an observer blinded to tissue identity as described previously (Duncan et al. 2005a).

\section{Acknowledgements}

The authors would like to thank the patients, clinical fellows, embryologists and nursing staff of the Edinburgh Assisted Conception Unit for help in sample collection. We would also like to thank Sheila MacPherson for histological advice and assistance, Dr Vincent Bombail for providing oestradiol and Prof. Philippa Saunders for helpful discussion. The research was supported by the Cunningham Trust (SvdD, WCD). MM is supported by an Overseas Research Student (ORS) Award Scheme. The authors declare that there is no conflict of interest that would prejudice the impartiality of this scientific work.

\section{References}

Andersen CY \& Hornnes P 1994 Intrafollicular concentrations of free cortisol close to follicular rupture. Human Reproduction 9 1944-1949.

Byers M, Kuiper GG, Gustafsson JA \& Park-Sarge OK 1997 Estrogen receptor-beta mRNA expression in rat ovary: down-regulation by gonadotropins. Molecular Endocrinology 11 172-182.

Cao G, O'Brien CD, Zhou Z, Sanders SM, Greenbaum JN, Makrigiannakis A \& Delisser HM 2002 Involvement of human PECAM-1 in angiogenesis and in vitro endothelial cell migration. American Journal of Physiology. Cell Physiology 282 C1181-C1190.

Casagrandi D, Bearfield C, Geary J, Redman CW \& Muttukrishna S 2003 Inhibin, activin, follistatin, activin receptors and beta-glycan gene expression in the placental tissue of patients with pre-eclampsia. Molecular Human Reproduction 9 199-203.

Chandrasekher YA, Melner MH, Nagalla SR \& Stouffer RL 1994 Progesterone receptor, but not estradiol receptor, messenger ribonucleic acid is expressed in luteinizing granulosa cells and the corpus luteum in rhesus monkeys. Endocrinology 135 307-314.

Chiang CH, Cheng KW, Igarashi S, Nathwani PS \& Leung PC 2000 Hormonal regulation of estrogen receptor alpha and beta gene expression in human granulosa-luteal cells in vitro. Journal of Clinical Endocrinology and Metabolism 85 3828-3839.

Critchley HO, Brenner RM, Henderson TA, Williams K, Nayak NR, Slayden OD, Millar MR \& Saunders PT 2001 Estrogen receptor beta, but not estrogen receptor alpha, is present in the vascular endothelium of the human and nonhuman primate endometrium. Journal of Clinical Endocrinology and Metabolism 86 1370-1378.

Critchley HO, Henderson TA, Kelly RW, Scobie GS, Evans LR, Groome NP \& Saunders PT 2002 Wild-type estrogen receptor (ERbeta1) and the splice variant (ERbetacx/beta2) are both expressed within the human endometrium throughout the normal menstrual cycle. Journal of Clinical Endocrinology and Metabolism 87 5265-5273. 
Devoto L, Vega M, Kohen P, Castro O, Carvallo P \& Palomino A 2002a Molecular regulation of progesterone secretion by the human corpus luteum throughout the menstrual cycle. Journal of Reproductive Immunology 55 11-20.

Devoto L, Kohen P, Vega M, Castro O, Gonzalez RR, Retamales I, Carvallo P, Christenson LK \& Strauss JF $2002 b$ Control of human luteal steroidogenesis. Molecular and Cellular Endocrinology 186 137-141.

Duffy DM, Chaffin CL \& Stouffer RL 2000 Expression of estrogen receptor alpha and beta in the rhesus monkey corpus luteum during the menstrual cycle: regulation by luteinizing hormone and progesterone. Endocrinology 141 1711-1717.

Duncan WC 2000 The human corpus luteum: remodelling during luteolysis and maternal recognition of pregnancy. Reviews of Reproduction $\mathbf{5}$ 12-17.

Duncan WC, McNeilly AS \& Illingworth PJ 1996 Expression of tissue inhibitor of metalloproteinases-1 in the human corpus luteum after luteal rescue. Journal of Endocrinology 148 59-67.

Duncan WC, Rodger FE \& Illingworth PJ 1998a The human corpus luteum: reduction in macrophages during simulated maternal recognition of pregnancy. Human Reproduction 13 2435-2442.

Duncan WC, McNeilly AS \& Illingworth PJ 1998b The effect of luteal 'rescue' on the expression and localization of matrix metalloproteinases and their tissue inhibitors in the human corpus luteum. Journal of Clinical Endocrinology and Metabolism 83 2470-2478.

Duncan WC, Gay E \& Maybin JA 2005a The effect of human chorionic gonadotrophin on the expression of progesterone receptors in human luteal cells in vivo and in vitro. Reproduction 130 83-93.

Duncan WC, Hillier SG, Gay E, Bell J \& Fraser HM 2005b Connective tissue growth factor expression in the human corpus luteum: paracrine regulation by human chorionic gonadotropin. Journal of Clinical Endocrinology and Metabolism 90 5366-5376.

Fraser HM \& Duncan WC 2005 Vascular morphogenesis in the primate ovary. Angiogenesis 8 101-116.

Fraser HM, Bell J, Wilson H, Taylor PD, Morgan K, Anderson RA \& Duncan WC 2005 Localization and quantification of cyclic changes in the expression of endocrine gland vascular endothelial growth factor in the human corpus luteum. Journal of Clinical Endocrinology and Metabolism 90 427-434.

Hansel W, Concannon PW \& Lukaszewska JH 1973 Corpora lutea of the large domestic animals. Biology of Reproduction 8 222-245.

Harlow CR, Bradshaw AC, Rae MT, Shearer KD \& Hillier SG 2007 Oestrogen formation and connective tissue growth factor expression in rat granulosa cells. Journal of Endocrinology 192 41-52.

Henderson TA, Saunders PT, Moffett-King A, Groome NP \& Critchley HO 2003 Steroid receptor expression in uterine natural killer cells. Journal of Clinical Endocrinology and Metabolism 88 440-449.

Hosokawa K, Ottander U, Wahlberg P, Ny T, Cajander S \& Olofsson IJ 2001 Dominant expression and distribution of oestrogen receptor beta over oestrogen receptor alpha in the human corpus luteum. Molecular Human Reproduction 7 137-145.

Hutchison JS, Nelson PB \& Zeleznik AJ 1986 Effects of different gonadotropin pulse frequencies on corpus luteum function during the menstrual cycle of rhesus monkeys. Endocrinology 119 1964-1971.

Hyder SM, Nawaz Z, Chiappetta C \& Stancel GM 2000 Identification of functional estrogen response elements in the gene coding for the potent angiogenic factor vascular endothelial growth factor. Cancer Research $603183-3190$

Ji Q, Chen P, Aoyoma C \& Liu P 2002 Increased expression of human luteinizing hormone/human chorionic gonadotropin receptor mRNA in human endometrial cancer. Molecular and Cellular Probes 16 269-275.

Kirwan RP, Leonard MO, Murphy M, Clark AF \& O'Brien CJ 2005 Transforming growth factor-beta-regulated gene transcription and protein expression in human GFAP-negative lamina cribrosa cells. Glia $\mathbf{5 2}$ 309-324.

Klauber N, Parangi S, Flynn E, Hamel E \& D'Amato RJ 1997 Inhibition of angiogenesis and breast cancer in mice by the microtubule inhibitors 2-methoxyestradiol and taxol. Cancer Research 57 81-86.

Matthews J \& Gustafsson JA 2003 Estrogen signaling: a subtle balance between ER alpha and ER beta. Molecular Interventions 3 281-292.

Maybin JA \& Duncan WC 2004 The human corpus luteum: which cells have progesterone receptors? Reproduction 128 423-431.
McCracken JA, Glew ME \& Scaramuzzi RJ 1970 Corpus luteum regression induced by prostagland in F2-alpha. Journal of Clinical Endocrinology and Metabolism 30 544-546.

Misao R, Nakanishi Y, Sun WS, Fujimoto J, Iwagaki S, Hirose R \& Tamaya T 1999 Expression of oestrogen receptor alpha and beta mRNA in corpus luteum of human subjects. Molecular Human Reproduction 5 17-21.

Mooberry SL 2003 Mechanism of action of 2-methoxyestradiol: new developments. Drug Resistance Updates 6 355-361.

Myers M, Gay E, McNeilly AS, Fraser HM \& Duncan WC 2007a In vitro evidence suggests activin-A may promote tissue remodeling associated with human luteolysis. Endocrinology 148 3730-3739.

Myers M, Lamont MC, van den Driesche S, Mary N, Thong KJ, Hillier SG \& Duncan WC $2007 \mathrm{~b}$ Role of luteal glucocorticoid metabolism during maternal recognition of pregnancy in women. Endocrinology $\mathbf{1 4 8}$ 5769-5779.

Niswender GD, Juengel JL, Silva PJ, Rollyson MK \& McIntush EW 2000 Mechanisms controlling the function and life span of the corpus luteum. Physiological Reviews 80 1-29.

Ogawa S, Inoue S, Watanabe T, Orimo A, Hosoi T, Ouchi Y \& Muramatsu M 1998 Molecular cloning and characterization of human estrogen receptor betacx: a potential inhibitor ofestrogen action in human. Nucleic Acids Research 26 3505-3512.

Oskarsson A, Ulleras E, Plant KE, Hinson JP \& Goldfarb PS 2006 Steroidogenic gene expression in H295R cells and the human adrenal gland: adrenotoxic effects of lindane in vitro. Journal of Applied Toxicology 26 484-492.

Rae MT, Niven D, Critchley HO, Harlow CR \& Hillier SG 2004 Antiinflammatory steroid action in human ovarian surface epithelial cells. Journal of Clinical Endocrinology and Metabolism 89 4538-4544.

Reynolds LP, Grazul-Bilska AT \& Redmer DA 2000 Angiogenesis in the corpus luteum. Endocrine 12 1-9.

Ruohola JK, Valve EM, Karkkainen MJ, Joukov V, Alitalo K \& Harkonen PL 1999 Vascular endothelial growth factors are differentially regulated by steroid hormones and antiestrogens in breast cancer cells. Molecular and Cellular Endocrinology 149 29-40.

Sar M \& Welsch F 1999 Differential expression of estrogen receptor-beta and estrogen receptor-alpha in the rat ovary. Endocrinology 140 963-971.

Saunders PT, Millar MR, Williams K, Macpherson S, Harkiss D, Anderson RA, Orr B, Groome NP, Scobie G \& Fraser HM 2000 Differential expression of estrogen receptor-alpha and -beta and androgen receptor in the ovaries of marmosets and humans. Biology of Reproduction 63 1098-1105.

Shifren JL, Tseng JF, Zaloudek CJ, Ryan IP, Meng YG, Ferrara N, Jaffe RB \& Taylor RN 1996 Ovarian steroid regulation of vascular endothelial growth factor in the human endometrium: implications for angiogenesis during the menstrual cycle and in the pathogenesis of endometriosis. Journal of Clinical Endocrinology and Metabolism 81 3112-3118.

Stouffer RL 2003 Progesterone as a mediator of gonadotrophin action in the corpus luteum: beyond steroidogenesis. Human Reproduction Update 9 99-117.

Taylor AH \& Al-Azzawi F 2000 Immunolocalisation of oestrogen receptor beta in human tissues. Journal of Molecular Endocrinology 24 145-155.

Telleria CM, Zhong L, Deb S, Srivastava RK, Park KS, Sugino N, Park-Sarge OK \& Gibori G 1998 Differential expression of the estrogen receptors alpha and beta in the rat corpus luteum of pregnancy: regulation by prolactin and placental lactogens. Endocrinology 139 2432-2442.

Tinley TL, Leal RM, Randall-Hlubek DA, Cessac JW, Wilkens LR, Rao PN \& Mooberry SL 2003 Novel 2-methoxyestradiol analogues with antitumor activity. Cancer Research 63 1538-1549.

Vega M \& Devoto L 1997 Autocrine/paracrine regulation of normal human corpus luteum development. Seminars in Reproductive Endocrinology 15 353-362.

Wulff C, Dickson SE, Duncan WC \& Fraser HM 2001 Angiogenesis in the human corpus luteum: simulated early pregnancy by HCG treatment is associated with both angiogenesis and vessel stabilization. Human Reproduction 16 2515-2524.

Received 21 September 2007

First decision 20 November 2007

Accepted 3 January 2008 